\title{
Studi Karakter Fisik dan Fisiologi Buah dan Benih Tomat (Solanum lycopersicum L.) Tora IPB
}

Physical Characteristic and Physiology of Tomatto Fruit and Seed (Solanum lycopersicum L.) Tora IPB

\author{
Mercy Julinda Zebua, Tatiek Kartika Suharsi", Muhamad Syukur
}

\author{
Departemen Agronomi dan Hortikultura, Fakultas Pertanian, Institut Pertanian Bogor \\ (Bogor Agricultural University), Jl. Meranti, Kampus IPB Darmaga, Bogor 16680, Indonesia \\ Telp.\& Faks.62-251-8629353 e-mail agrohort@apps.ipb.ac.id \\ *Penulis Korespondensi : t.suharsi@yahoo.co.id
}

Disetujui : 21 Mei 2018 / Published Online 2 Januari 2019

\begin{abstract}
Tomato (Solanum lycopersicum L.) is one of cultivated horticulture plants in Indonesia. The availability of quality seeds is still relatively low because it is influenced by several factors. One of the factors that affect the quality of the resulting seed is the age of the fruit when harvested. Fruit that was harvested when the fruit has reached the physiological maturity produce high quality seeds. The purpose of this research was to obtain the physical fruit and physiology seed character of Tora-IPB tomato at the maturation period. The experimental design used in this research was a randomized completed block design. This research was conducted at Cikabayan Experimental Garden, IPB since February 2017 - August 2017. The character observed was physical fruit and physiology seed. The results of this study was the age of fruit affect the physical character of the fruit was the color and softness of the fruit. The fruit age did not affect the physiological character of the seeds germination and vigor index. The quality of Tora-IPB tomato seeds in this study can not be determined, because the seeds from harvested fruit 35 HSB-50 HSB viability $39.10-49.00 \%$ and vigor $12.97-20.00 \%$. The condition of Tora-IPB tomato plants that were low in vigor and many disease attacked also cause fruit development was not optimal, as well as the physiological quality of the seed.
\end{abstract}

Keywords: physiology maturation, fruit age, seed quality

\begin{abstract}
ABSTRAK
Tomat (Solanum lycopersicum L.) merupakan salah satu jenis tanaman hortikultura yang banyak dibudidayakan di Indonesia. Ketersediaan benih yang bermutu masih tergolong rendah karena dipengaruhi oleh beberapa faktor. Salah satu faktor yang berpengaruh terhadap mutu benih yang dihasilkan adalah umur buah pada saat dipanen. Buah yang dipanen saat buah telah mencapai masak fisiologi menghasilkan benih yang berkualitas. Tujuan penelitian ini adalah mendapatkan karakter fisik buah dan fisiologi benih tomat varietas Tora-IPB pada periode pemasakan. Rancangan percobaan yang digunakan dalam penelitian ini adalah Rancangan Kelompok Lengkap Teracak (RKLT). Penelitian ini dilaksanakan di Kebun Percobaan Cikabayan, IPB sejak bulan Februari 2017- Agustus 2017. Karakter yang diamati adalah karakter fisik buah dan fisiologi benih. Hasil penelitian ini adalah umur buah mempengaruhi karakter fisik buah yaitu pada warna dan kelunakan buah. Umur buah tidak mempengaruhi karakter fisiologi benih yaitu daya berkecambah dan indeks vigor. Mutu benih tomat Tora-IPB pada penelitian ini belum bisa ditentukan, karena benih dari buah yang dipanen 35 HSB-50 HSB viabilitasnya $39.10-49.00 \%$ dan vigornya $12.97-20.00 \%$. Kondisi tanaman tomat Tora-IPB yang bervigor rendah dan banyak serangan penyakit juga menyebabkan perkembangan buah tidak optimal, demikian juga mutu fisiologis benihnya.
\end{abstract}

Kata kunci: masak fisiologi, umur buah, mutu benih. 


\section{PENDAHULUAN}

Tanaman hortikultura merupakan salah satu jenis tanaman yang dibudidayakan di Indonesia. Produk tanaman hortikultura di Indonesia masih sangat terbatas. Berdasarkan data dari Kementrian Pertanian (2015), neraca perdagangan produk hortikultura masih mengalami defisit. Kondisi defisit neraca perdagangan hortikultura terutama terjadi pada kelompok komoditas buah dan sayuran. Jenis tanaman sayuran yang memberikan kontribusi produksi terbesar terhadap total produksi sayuran di Indonesia adalah kol/kubis $(12.05 \%)$, kentang $(11.31 \%)$, bawang merah $(10.35 \%)$, cabai besar $(9.02 \%)$ dan tomat $(7.09 \%)$. Produksi tomat pada tahun 2015 yaitu 4.17 ton. Tomat mengalami penuruan produksi dari tahun 2013 hingga 2015 (Kementrian Pertanian, 2016).

Budidaya tanaman tomat tidak terlalu sulit dan tidak membutuhkan biaya yang mahal, namun terdapat beberapa faktor yang mempengaruhi kualitas dan kuantitas produksi tanaman tomat. Salah satu faktor yang berpengaruh adalah mutu benih yang digunakan. Menurut Thomas et al. (2017) mutu benih terbagi tiga yaitu mutu fisik, fisiologi dan genetik. Menurut Jones (2007), mutu fisik benih adalah kondisi dimana benih tidak mengalami kerusakan, bebas dari kontaminan seperti benih gulma dan bebas dari pathogen. Mutu fisik benih dideteksi berdasarkan kemurnian fisik dan bebas dari kotoran yang tidak diinginkan. Menurut Suharsi et al. (2013) mutu fisik benih terlihat dari kinerja fisiknya yang bersih dari kotoran yang terbawa dari lapang (kotoran fisik) dan ukuran benih seragam. Mutu fisiologi benih adalah tinggi rendahnya daya hidup atau viabilitas benih yang tercermin dari nilai daya berkecambah, kecepatan tumbuh dan keserempakan tumbuh. Mutu genetik menunjukkan benih mempunyai keseragaman genetik yang tinggi dan tidak tercampur varietas lain. Gregg dan Billups (2010) menyatakan bahwa mutu genetik benih adalah kemurnian varietas dari benih tersebut, dan kemampuan benih untuk memberikan manfaat penuh dari potensial genetik dan varietas yang dimilikinya.

Benih tomat yang terdapat dalam buah tomat yang berdaging bisa ditentukan masak fisiologinya dengan menandai karakter fisiknya yaitu warna buah, panjang buah, diameter buah, bobot buah, dan kekerasan/kelunakan buah. Karakteristik buah Tora-IPB pada saat benihnya mencapai masak fisiologi belum diketahui, sehingga diperlukan penelitian untuk mengetahui karakter fisik buah dan karakter fisiologi benih pada tomat Tora-IPB.
Tujuan penelitian ini adalah mempelajari karakter fisik buah dan karakter fisiologi benih tomat varietas Tora-IPB pada saat masak fisiologi benih.

\section{BAHAN DAN METODE}

Penelitian ini dilaksanakan di rumah kaca Kebun Percobaan Cikabayan, Laboratorium Penyimpanan dan Pengujian Kualitas Benih, Institut Pertanian Bogor, Dramaga dan Laboratorium Kering Pengujian Mutu Benih Baranangsiang, Bogor. Kegiatan penelitian dimulai pada bulan Februari 2017-Agustus 2017. Bahan yang digunakan dalam penelitian ini adalah benih tomat varietas Tora IPB. Pupuk yang digunakan yaitu pupuk kandang sapi. Pupuk dasar juga digunakan dalam penelitian ini, yaitu NPK mutiara $(\mathrm{N}=16, \mathrm{P}=16, \mathrm{~K}=16)$. Bahan lain yang digunakan adalah pestisida. Alat yang digunakan adalah peralatan budidaya tanaman, tray semai, polibag, ajir bambu, meteran, kertas buram, label, cawan petri, pinset, oven, desikator, germinator (alat pengecambah benih), penetrometer, jangka sorong dan alat tulis.

Rancangan percobaan yang digunakan dalam penelitian ini adalah Rancangan Kelompok Lengkap Teracak (RKLT) dengan 6 taraf peubah umur panen dan 4 ulangan, sehingga terdapat 24 satuan percobaan. Tiap satuan percobaan digunakan minimal 1 buah tomat. Taraf peubah umur panen yang digunakan dalam penelitian ini adalah 35, 38, 41, 44, 47 dan 50 HSB (Hari Setelah Berbunga).

Tahap awal yang dilakukan dalam penelitian ini adalah penyemaian benih tomat. Penyemaian benih dilakukan dengan menggunakan tray sebagai wadah penyemaian. Media tanam yang digunakan adalah tanah, pupuk kandang, dan sekam padi dengan perbandingan 1:1:1. Langkah selanjutnya yang dilakukan adalah persiapan tanam. Persiapan tanam yang dilakukan sebelum proses penanaman adalah penyiapan media tanam. Media tanam yang digunakan adalah tanah. Media tanam kemudian dimasukkan dalam polibag berukuran $30 \mathrm{~cm}$ x $30 \mathrm{~cm}$. Tanaman yang telah berumur 5 minggu (mempunyai 4-5 helai daun) setelah semai dipindah tanam ke dalam polibag. Pemasangan lenjeran juga perlu dilakukan untuk mengikatkan tanaman agar tidak rebah. Lenjeran dibuat dari bambu sepanjang $1.5 \mathrm{~m}-2 \mathrm{~m}$. Lenjeran ditancapkan di samping tanaman. Pemasangan lenjeran dilakukan setelah tinggi tanaman berkisar $10 \mathrm{~cm}-15 \mathrm{~cm}$ yaitu pada umur 5 minggu setelah pindah tanam ke polibag. 
Pemeliharaan dan perawatan yang dilakukan pada tanaman tomat cukup intensif karena tanaman cukup rentan terhadap hama penyakit. Beberapa hal yang dilakukan untuk pemeliharaan dan perawatan tanaman ini adalah: penyulaman, penyiangan dan penyiraman. Penyulaman dilakukan seminggu setelah tomat ditanam. Tanaman yang disulam adalah tanaman yang terlihat tidak sehat atau mati. Penyiangan juga perlu dilakukan agar tidak terdapat tumbuhan lain yang mengganggu pertumbuhan tanaman tomat. Penyiraman disesuaikan dengan cuaca, sehingga tidak terjadi kelebihan air dan kekurangan air.

Pemanenan dilakukan menurut tingkat kemasakan dari fase buah muda hingga buah masak. Buah tomat diambil mulai 35, 38, 41, 44, 47, 50 HSB. Buah yang telah dipanen dilakukan pengamatan terhadap karakter fisik buah yaitu warna, panjang, diameter, bobot serta kekerasan/kelunakan buah. Benih yang berasal dari buah yang telah diamati kemudian diuji viabilitas dan vigornya. Pemanenan dapat dilakukan pada kisaran umur 60-100 hari setelah tanam. Buah tomat sudah siap panen apabila kulit buah sudah mencapai kriteria sesuai dengan skala warna buah dan bagian tepi daun menguning. Buah yang telah dipanen diekstraksi secara manual, kemudian benih yang telah dikeluarkan dari buah difermentasi selama 36 jam. Langkah selanjutnya setelah fermentasi adalah membersihkan benih dengan menggunakan air bersih untuk menghilangkan pulp dari benih agar tidak menghambat proses perkecambahan pada benih. Benih yang telah dibersihkan, dikeringkan dengan dijemur benih pada sinar matahari selama 4-5 jam / hari.

Pengamatan masak fisiologi dilakukan berdasarkan 2 karakter yaitu, karakter fisik buah dan karakter fisiologi benih tomat Tora IPB. Pengamatan karakter fisik yang dilakukan yaitu warna buah, panjang buah, kekerasan/kelunakan buah, diameter buah dan bobot buah. Pengamatan karakter fisiologi yang dilakukan adalah daya berkecambah dan indeks vigor.

\section{HASIL DAN PEMBAHASAN}

\section{Kondisi Umum}

Tanaman tomat merupakan salah satu tanaman dari famili Sollanaceae yang rentan terhadap berbagai hama dan penyakit. Selama pemeliharaaan tanaman Tora-IPB di lapang, terdapat berbagai hama dan penyakit yang menyerang tanaman. Hama dan penyakit tersebut sangat mengganggu pertumbuhan dan perkembangan tanaman, bahkan beberapa tanaman mengalami kematian pada fase vegetatif maupun pada awal generatif. Hama yang menyerang tanaman di lapang adalah ulat grayak (Spodoptera litura F.), ulat ini dapat ditemukan di permukaan daun tanaman tomat. Buah tomat juga diserang oleh ulat buah tomat (Helicoverpa armigera Hubn.) gejala serangannya adalah buahbuah tomat muda yang berlubang. Buah tomat yang terserang menjadi busuk dan jatuh. Kutu juga menyerang tanaman tomat pada masa vegetatif.

Penyakit juga termasuk faktor yang menyerang tanaman tomat, sehingga mempengaruhi pertumbuhan dan produksi dari tanaman tomat. Penyakit yang banyak menyerang adalah penyakit layu yang disebabkan oleh bakteri (Pseudomonas ralstonia) dan virus. Gejala serangan ditandai dengan tanaman layu secara tiba-tiba pada sebagian daunnya dan berlanjut pada seluruh daun lalu mengering dan akhirnya mati. Penyakit layu merupakan penyakit yang paling banyak menyerang tanaman Tora-IPB selama penelitian. Penyakit yang disebabkan oleh virus pada penelitian ini disebut dengan rugosa. Rugosa adalah penyakit yang menyerang daun tomat. Penyakit rugosa menyebabkan permukaan daun yang tidak rata yang disebabkan oleh pertumbuhan urat daun tidak sebanding dengan pertumbuhan helai daun, sehingga daun akan terlihat tidak rata dengan permukaan yang benjolbenjol. Pemberantasan hama dan penyakit yang telah dilakukan adalah menyemprotkan agrimac 2 $\mathrm{ml} \mathrm{L}^{-1}$.

Kondisi iklim selama penelitian juga mempengaruhi pertumbuhan tanaman tomat ToraIPB selama penelitian. Menurut data dari BMKG Bogor (2017) kelembaban pada saat perkecambahan pada bulan Februari-April cukup tinggi yaitu $85 \%$, sehingga rawan terserang penyakit. Menurut Wiryanta (2002), kelembaban relatif yang diperlukan tanaman tomat selama pertumbuhan adalah $80 \%$, kelembaban yang terlalu tinggi dapat menyebabkan tanaman tomat mudah terserang bakteri dan cendawan.

\section{Pengamatan Karakter Fisik Buah Tomat Tora- IPB}

\section{Warna Buah}

Pematangan buah tomat disertai oleh perubahan warna, kekerasan, dan perubahan rasa dan aroma (Kader, 2002). Menurut Teka (2013), warna dan kekerasan adalah karakteristik yang digunakan untuk menentukan kematangan buah. Hal yang sama juga dikemukakan oleh Zhang and McCharthy (2012), bahwa kematangan buah tomat berhubungan dengan parameter yang dapat diukur yaitu kekerasan dan warna buah yang 
mencerminkan perubahan biokimia selama pemasakan. Warna buah adalah salah satu hal paling penting yang menentukan keseluruhan kualitas dari buah tersebut. Perubahan terjadi ketika warna tomat berubah dari hijau ke merah terang (Heuvelink, 2005). Warna pada buahbuahan dan sayuran disebabkan oleh pigmen yang dikandungnya. Pigmen secara umum terbagi ke dalam empat kelompok yaitu klorofil, antosianin, flavonoid, dan karotenoid (Winarno, 2002). Buah tomat mengandung pigmen karotenoid, terutama likopen dan $\beta$-karoten yang merupakan komponen utama penentu warna pada buah tomat masak (Novita et al., 2015).

Menurut Cantwell (2000), komposisi buah tomat khususnya kandungan likopen dan $\beta$ karoten pada tingkat kematangan mature-green, breaker dan red-ripe (Tabel 1.) adalah:

Tabel 1. Komposisi likopen dan $\beta$-karoten pada berbagai tingkat kematangan buah tomat (Cantwell,2000)

\begin{tabular}{lcc}
\hline $\begin{array}{l}\text { Tingkat } \\
\text { kematangan }\end{array}$ & $\begin{array}{c}\text { Likopen } \\
(\mu \mathrm{g} / \mathrm{g})\end{array}$ & $\begin{array}{c}\beta-\text { Karoten } \\
(\mu \mathrm{g} / \mathrm{g})\end{array}$ \\
\hline Mature-green & 0.00 & 0.00 \\
Breaker & 0.52 & 0.40 \\
Red-ripe & 48.3 & 4.33 \\
\hline
\end{tabular}

Kandungan likopen dan $\beta$-karoten tertinggi terdapat pada buah tomat dengan tingkat kematangan red-ripe. Menurut Thompson et al. (2000), tingkat likopen secara langsung berhubungan dengan pematangan pada buah tomat.

Warna buah tomat Tora-IPB mencapai tingkat kematangan red-ripe pada umur 50 HSB (Hari Setelah Berbunga) berdasarkan penelitian yang telah dilakukan. Buah tomat Tora-IPB pada umur 35 HSB memiliki warna mature-green, umur 38 HSB memiliki warna breaker-turning, 41 HSB memilki warna pink, umur 44 HSB memiliki warna light-red, 47 HSB memilki warna pinklight-red (Gambar 1). Perubahan warna buah tomat pada tingkat umur buah yang berbeda menunjukkan bahwa kandungan likopen pada buah tomat terus mengalami peningkatan.

Proses pematangan pada buah tomat juga dipengaruhi oleh menurunnya kandungan klorofil pada buah tersebut (Heuvelink, 2005). Pernyataan ini berhubungan dengan penelitian yang telah dilakukan oleh Karki (2005). Penelitian tersebut menunjukkan tingkat kandungan klorofil (mg/100 g) pada masing-masing tingkat kemasakan buah tomat yaitu 1.78 pada mature-green, 0.93 pada breaker, 0.76 pada turning dan 0.59 pada pink. Tingkat kematangan yang direkomendasikan untuk pemanenan adalah ketika kulit/permukaan buah berwarna merah lebih dari $90 \%$.
Warna buah tomat Tora-IPB mencapai tingkat kematangan red-ripe pada umur $50 \mathrm{HSB}$ (Hari Setelah Berbunga) berdasarkan penelitian yang telah dilakukan. Buah tomat Tora-IPB pada umur 35 HSB memiliki warna mature-green, umur 38 HSB memiliki warna breaker-turning, 41 HSB memilki warna pink, umur 44 HSB memiliki warna light-red, 47 HSB memilki warna pinklight-red (Gambar 1). Perubahan warna buah tomat pada tingkat umur buah yang berbeda menunjukkan bahwa kandungan likopen pada buah tomat terus mengalami peningkatan.

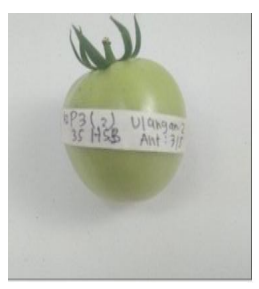

(a)

35 HSB

(mature-green)

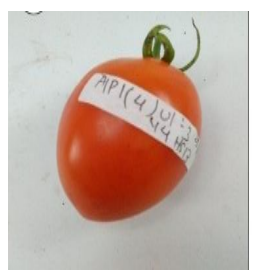

(d)

$44 \mathrm{HSB}$

(light-red)

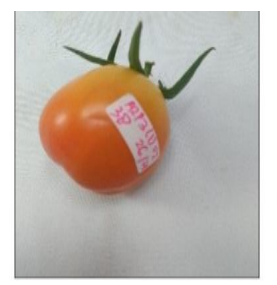

(b)

38 HSB

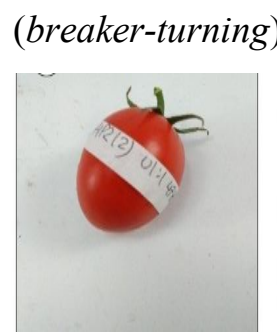

(e)

47 HSB

(pink-light red)

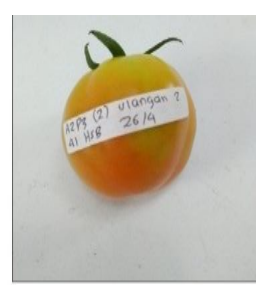

(c)

41 HSB

(pink)

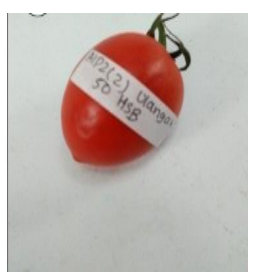

(f)

$50 \mathrm{HSB}$

(red-ripe)
Gambar 1. Warna buah tomat Tora-IPB pada umur berbeda

Proses pematangan pada buah tomat juga dipengaruhi oleh menurunnya kandungan klorofil pada buah tersebut dan berhubungan dengan penelitian yang telah dilakukan oleh Karki (2005). Penelitian tersebut menunjukkan tingkat kandungan klorofil (mg/100 g) pada masingmasing tingkat kemasakan buah tomat yaitu 1.78 pada mature-green, 0.93 pada breaker, 0.76 pada turning dan 0.59 pada pink. Tingkat kematangan yang direkomendasikan untuk pemanenan adalah ketika kulit/permukaan buah berwarna merah lebih dari $90 \%$.

\section{Panjang, Diameter Buah dan Bobot Buah}

Panjang dan diameter buah merupakan ciri dari buah tomat yang matang. Okiror et al. (2017) menyatakan bahwa panjang dan diameter buah adalah indeks yang penting untuk menentukan kematangan buah tomat. Panjang, diameter dan bobot buah tomat Tora-IPB pada penelitian ini tidak dipengaruhi umur buah (Tabel 2.). Hal ini disebabkan buah tomat umur 35 HSB ukurannya sudah mencapai maksimum sesuai dengan Wu dan Kubota (2008), buah tomat mencapai ukuran 
Tabel 2. Pengaruh umur buah terhadap karakteristik fisik buah tomat Tora-IPB

\begin{tabular}{lccccccc}
\hline \multirow{2}{*}{ Karakteristik } & \multicolumn{7}{c}{ Umur Hari Setelah Berbunga (UHSB) } \\
\cline { 2 - 7 } & 35 & 38 & 41 & 44 & 47 & 50 & Uji-F \\
\hline Warna & $1.26 \mathrm{~d}$ & $2.94 \mathrm{c}$ & $3.67 \mathrm{bc}$ & $4.55 \mathrm{~b}$ & $4.46 \mathrm{~b}$ & $5.88 \mathrm{a}$ & $*$ \\
Panjang (cm) & 4.509 & 4.313 & 4.507 & 4.465 & 4.963 & 4.398 & tn \\
Diameter (cm) & 3.441 & 3.725 & 3.835 & 3.473 & 3.927 & 3.508 & tn \\
Bobot (g) & 36.520 & 39.560 & 48.873 & 37.003 & 42.520 & 39.378 & tn \\
Kelunakan (mm/(gr.sec) & $0.017 \mathrm{~b}$ & $0.023 \mathrm{a}$ & $0.018 \mathrm{~b}$ & $0.021 \mathrm{ab}$ & $0.023 \mathrm{a}$ & $0.025 \mathrm{a}$ & $*$ \\
\hline
\end{tabular}

Keterangan : Angka yang disertai huruf berbeda pada baris yang sama menunjukkan berbeda nyata $(\mathrm{P}<0.05), \mathrm{UHSB}=$ umur hari setelah berbunga. $*$ : berpengaruh nyata, tn: tidak berpengaruh nyata.

maksimum di akhir fase mature-green dan berubah ukuran setelah fase breaker.

Berdasarkan Tabel 2 panjang buah tomat Tora-IPB maksimum pada umur 47 HSB (Hari Setelah Berbunga) yaitu $4.96 \mathrm{~cm}$ dengan diameter buah yaitu $3.93 \mathrm{~cm}$. Perbedaan panjang buah yang fluktuatif pada setiap umur buah disebabkan karena perbedaan nilai rata-rata ukuran buah tiap tanaman yang dipanen.

Menurut Moneruzzaman (2008), tingkat kemasakan buah tomat merupakan salah satu faktor yang mempengaruhi kehilangan bobot dari buah tersebut. Berdasarkan penelitian yang telah dilakukan, bobot buah tomat terkecil diperoleh pada tingkat mature-green (umur $35 \mathrm{HSB}$ ) yaitu 36.52 gram (Tabel 2). Hal ini sesuai dengan penelitian Moneruzzaman (2008) yang menyatakan bahwa kehilangan bobot tertinggi terjadi pada buah tomat mature-green karena tingkat dehidrasi tertinggi terjadi dalam jaringan yang muda. Bobot tertinggi buah tomat Tora-IPB diperoleh pada umur 41 HSB yaitu pada tingkat kemasakan pink yaitu 48.87 gram.

\section{Kelunakan Buah}

Berdasarkan hasil analisis menunjukkan bahwa umur buah tomat Tora-IPB berpengaruh nyata $(\mathrm{P}<0.05)$ terhadap kelunakan buah tomat Tora-IPB. Menurut Teka (2013) dan Moneruzzaman (2008), kekerasan buah tomat terkait dengan kerentanan buah terhadap kerusakan fisik saat panen dan penyimpanan yang tergantung pada tingkat kemasakan buah.

Kelunakan buah yang semakin tinggi menunjukkan bahwa buah tomat semakin lunak. Hasil penelitian menunjukkan bahwa buah tomat pada umur $50 \mathrm{HSB}$ yaitu $0.025 \mathrm{~mm} /(\mathrm{gr} . \mathrm{sec})$ merupakan nilai kelunakan yang paling besar (Tabel 2). Hal ini disebabkan daging buah dan permukaan buah tomat mengalami pelunakan dibanding dengan umur buah tomat lainnya. Menurut Teka (2013), penurunan kekerasan buah pada tingkat kematangan tertentu berhubungan dengan degradasi polisakarida di dalam buah tomat. Omboki (2015) menambahkan bahwa pelunakan tekstur buah adalah perubahan tekstur yang penting pada buah klimakterik karena dinding sel hemiselulosa dan depolimerisasi dan solubilisasi pektin oleh jenis hidrolase.

\section{Pengamatan Karakter Fisiologi Benih Tanaman Tomat Tora-IPB}

\section{Daya Berkecambah}

Daya berkecambah adalah proses fisiologis yang kompleks yang responsif terhadap pengaruh lingkungan seperti potensial air, cahaya, suhu dan oksigen (Bhardwaj, 2016). Ukuran benih dan berat benih yang lebih besar memiliki viabilitas benih lebih baik dibandingkan dengan ukuran sedang, kecil dan ringan. Benih yang lebih besar mempunyai cadangan makanan yang lebih besar (Yuniarti, 2011). Penelitian-penelitian yang telah dilakukan sebelumnya menyatakan bahwa benih tomat mencapai daya berkecambah dan vigor maksimum pada buah yang berwarna merah (Dias, 2006). Daya berkecambah benih tomat Tora-IPB pada penelitian ini dapat dilihat pada Tabel 3.

Tabel 3. Daya berkecambah benih Tora-IPB

\begin{tabular}{cc}
\hline UHSB & Daya Berkecambah $(\%)$ \\
\hline 35 & 45.00 \\
38 & 42.50 \\
41 & 39.10 \\
44 & 49.00 \\
47 & 44.58 \\
50 & 46.35 \\
\hline Uji-F & tn \\
\hline
\end{tabular}

Keterangan : UHSB: umur hari setelah berbunga; tn : tidak berpengaruh nyata.

Rata-rata persentase daya berkecambah benih tomat Tora-IPB yang dihasilkan berdasarkan penelitian yang telah dilakukan menunjukkan bahwa daya berkecambah tertinggi terdapat pada benih dari umur buah 44 HSB yaitu $49 \%$ (Tabel 3).Waktu munculnya kecambah normal pada pengujian benih Tora-IPB yaitu pada 5 HST seperti pada (Gambar 2). Hal ini ditandai dengan rata-rata persentase daya berkecambah yang lebih tinggi dibandingkan dengan indeks vigor. Daya berkecambah yang rendah dari benih 
Tora-IPB yang diuji dapat disebabkan oleh beberapa faktor yaitu kondisi tanaman tomat yang tidak optimum karena terserang hama dan penyakit, pengisian benih tidak maksimal dan serangan penyakit pada saat pengujian benih di lab.

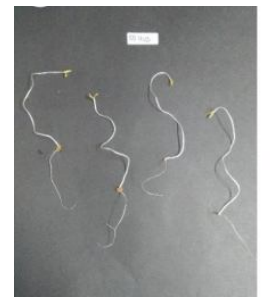

(a)

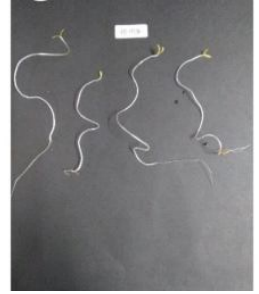

(b)

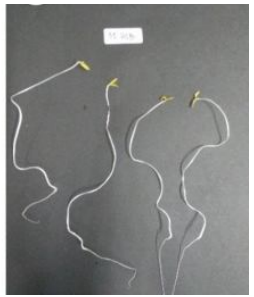

(c)
35 HSB

38 HSB

$50 \mathrm{HSB}$

Gambar 2. Struktur kecambah normal tomat ToraIPB pada umur 5 HST

Umur benih pada 3 HST (Hari Setelah Tanam) sebenarnya menghasilkan kecambah, namun kecambah yang dihasilkan bukan merupakan kecambah normal atau kecambah yang sempurna. Kecambah yang dihasilkan tidak menghasilkan bagian-bagian kecambah yang sempurna. Kecambah abnormal pada umur 3 HST seperti yang terlihat pada (Gambar 3).

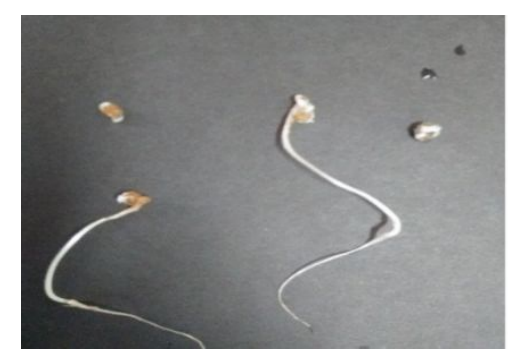

Gambar 3. Struktur kecambah abnormal tomat Tora-IPB pada umur 3 HST

Benih yang ditumbuhkan di media tidak dapat melakukan perkecambahan dengan baik, bagian-bagian dari kecambah tidak muncul secara sempurna, misalnya plumula tidak muncul (Gambar 3). Beberapa benih juga sama sekali tidak dapat berkecambah karena terserang jamur pada permukaan kulit benih.

\section{Indeks Vigor}

Vigor diartikan sebagai kemampuan benih untuk tumbuh pada lingkungan suboptimal. Menurut Sadjad dalam Immawati et al. (2013), tanaman dengan tingkat vigor tinggi dapat dilihat dari keragaan fenotip kecambahnya . Justice dan Louis dalam Pulungan et al. (2014) menyatakan bahwa indeks vigor berhubungan dengan kekuatan benih atau kekuatan kecambah yakni kemampuan benih untuk menghasilkan perakaran dan pucuk yang kuat pada kondisi yang menguntungkan dan bebas mikroorganisme. Benih mencapai vigor maksimum pada saat masak fisiologis. Benih yang dipanen setelah tercapainya masak fisiologi memiliki vigor yang relatif lebih tinggi sehingga menghasilkan tanaman yang lebih vigor dan memiliki daya simpan lebih lama. Benih dengan vigor tinggi dapat membentuk dan mentranslokasikan bahan baku ke poros embrio dengan cepat sehingga meningkatkan akumulasi bahan kering (Widiarti, 2016). Indeks vigor benih tomat Tora-IPB dapat dilihat pada Tabel 4.

Tabel 4. Indeks vigor benih Tora-IPB

\begin{tabular}{cc}
\hline UHSB & Indeks Vigor (\%) \\
\hline 35 & 18.17 \\
38 & 19.95 \\
41 & 17.25 \\
44 & 20.00 \\
47 & 15.75 \\
50 & 12.97 \\
\hline Uji-F & tn \\
\hline
\end{tabular}

Keterangan : UHSB: umur hari setelah berbunga; tn : tidak berpengaruh nyata.

Berdasarkan penelitian yang telah dilakukan pada pengujian benih tomat Tora-IPB berdasarkan umur buah pada enam taraf $(35,38$, 41, 44, 47 dan 50 HSB), indeks vigor yang dihasilkan masih tergolong rendah. Indeks vigor tertinggi dari semua ulangan terdapat pada benih dengan umur 44 HSB (Hari Setelah Berbunga) yaitu $20 \%$ seperti yang terlihat pada (Tabel 4 ). Angka $20 \%$ merupakan indeks vigor yang tergolong masih rendah. Indeks vigor yang dihasilkan pada umur buah (HSB) pada taraf yang lain $(35,38,41,47$ dan 50) adalah $18.17 \%$, $19.95 \%, 17.25 \%, 15.75 \%$ dan $12.97 \%$.

Berdasarkan hasil penelitian karakter fisik buah dan fisiologi benih tomat Tora-IPB, masak fisiologi benih dicapai pada umur 44 HSB untuk untuk daya berkecambah dan untuk indeks vigor.

\section{KESIMPULAN}

Mutu benih tomat Tora-IPB pada penelitian ini belum bisa ditentukan, karena benih dari buah yang dipanen 35 HSB-50 HSB viabilitasnya $39.10 \%-49.00 \%$ dan vigornya $12.97 \%-20.00 \%$. Kondisi tanaman tomat Tora-IPB yang bervigor rendah dan banyak serangan penyakit juga menyebabkan perkembangan buah tidak optimal, demikian juga mutu fisiologis benihnya.

\section{DAFTAR PUSTAKA}

Bhardwaj, A.K. 2016. Effect of various dormancy breaking treatments on seed germination, seedling growth and seed vigor of medical plants. J.Tropical Plant. 3(3): 508-516. 
Cantwell. 2000. Optimum Procedur for Ripening Tomatoes. University California, California.

Dias, D.C.F.S., F.P. Ribeiro, L.A.S. Dias, D.J.H Silva, D.S. Vidigal. 2006. Tomat seed quality in relation to fruit maturation and post-harvest storage. J. Seed Science and Technology. 34: 691-699.

Gregg, Billups. 2010. Seed Conditioning. CRC Press, USA.

Heuvelink. 2005. Tomatoes. CABI International, USA.

Immawati, D.R., S. Purwanti, D. Prajitno. 2013. Daya simpan benih kedelai hitam (GlycineMax (L) Merrill) hasil tumpangsari dengan sorgum manis (Shorgum Bicolor (L) Moench. J. Vegetika. 2(4): 25-34.

Jones, J.B. 2007. Tomatto Plant Culture. CRC Press, London.

Karki, D.B. 2005. Effect of harvesting stateson thr quality of tomato (Lycopersicon esculentum MILL cv. Avinash-2 Hybrid). Journal of Tribhuvan University. 1(25): 141-147.

Kader, A.A. 2002. Postharvest Technology of Horticultural Crops, 3rd edn. University of California, DANR Special Publications No. 3311.

Kementrian Pertanian. 2015. Rencana Strategis Kementrian Pertanian Tahun 2015-2019. Kementerian Pertanian RI, Jakarta.

Kementrian Pertanian. 2016. Produksi Sayuran di Indonesia Tahun 2013-2015. Kementrian Pertanian RI, Jakarta.

Moneruzzaman, K.M., A.B.M.S. Hosain, W. Sani, M. Saifudin. 2008. Effect of stage of maturity and ripening conditions on the physical characteristic of tomato. American Journal of Biochemistry and Biotechnology. 4(4): 329-335.

Novita, M., Satriana, H. Etria. 2015. Kandungan likopen dan karotenoid buah tomat (Lycopersicum pyriforme) pada berbagai tingkat kematangan: pengaruh pelapisan dengan kitosan dan penyimpanan. Jurnal Teknologi dan Industri Pertanian Indonesia. 7(1): 35-39.

Okiror, P., J.B. Lejju, J. Bahati, G.K. Rugunda, C.I. Sebuuwufy. 2017. Maturity indices for tomato (Solanum lycopersicum L.), cv. Ghalia 281 in central ugada. African Journal of Agricultural Research. 12(14): 1196-1203.
Omboki, R.B., W. Weiren, X. Xiaofang, M. Gandeka. 2015. Ripening genetics of the tomato fruit. International Journal of Agriculture and Crop Sciences. 8(4):567572.

Pulungan, D.M.S., Haryati, R.R. Lahay. 2014. Pengaruh periode panen terhadap viabilitas benih rosela (Hibiscus Sabdariffa L.). Jurnal Online Agroekoteknologi. 2(2): 878883.

Suharsi, T.K. 2013. Viabilitas, Parameter, dan Tolak Ukur Viabilitas Benih. Dalam E. Widajati, E. Murniati, E.R. Palupi, M.R. Suhartanto, A Qadir (eds.). Dasar Ilmu dan Teknologi Benih. IPB Press, Bogor.

Teka, T.A. 2013. Anlysis of the effect of maturity stage of the postharvest biochemical quality characteristic of tomato (Lycopersicum esculentum MILL.) fruit. International Journal of Pharmaceutical and Applied Sciences. 3(5): 180-186.

Thomas, B., B.G. Murray, D.J. Murphy. 2017. Encyclopedia of Applied Plant Sciences. Oxford.

Thompson, K.A., M.R. Marshall, C.A. Sims, C.I. Wei, S.A. Sargent, J.W. Scott. 2000. Cultivar, maturity, and heat treatment on lycopene content in tomatoes. Journal of Food Science. 65: 791-795.

Widiarti, W., W. Erni, R. Pudji. 2016. Respon vigor benih dan pertumbuhan awal tanaman tomat terhadap konsentrasi dan lama perendaman asam klorida ( $\mathrm{HCl})$. Jurnal Ilmu-ilmu Pertanian. 151-160.

Winarno, F.G. 2002. Fisiologi Lepas Panen Produk Hortikultura. Bogor.

Wiryanta. 2002. Bertanam Tomat. Agromedia Pustaka, Jakarta.

Wu, M., C. Kubota. (2008). Effects of high electrical conductivity of nutrient solution and its application timing on lycopene, chlorophyll and sugar concentrations of hydroponic tomatoes during ripening. Sci. Hortic. 116: 122-129.

Yuniarti, N., Megawati, B. Leksono. 2011. Pengaruh metode ekstraksi dan ukuran benih terhadap mutu fisik-fisiologis benih Acacia crassicarpa. J. Penelitian Hutan Tanaman. 10(3): 129-137.

Zhang, McCharty. 2012. Measurement and evaluation of tomatto maturity using magnetic resonance imaging. J. Postharvest BiologyTechnology. 67: 37-43. 